\title{
The Relation between Serum Progranulin and Platelet Count in Immune Thrombocytopenia Patients
}

\author{
Noha M. Attia, Adel M. Agha, Safaa E. Abass, Ola S. El-Shimi
}

\begin{abstract}
Department of clinical and chemical pathology, Faculty of Medicine, Benha University, Egypt.

Correspondence to: Noha M. Attia, department of clinical and chemical pathology, Faculty of Medicine, Benha university, Egypt.
\end{abstract}

Email:

nattia432@gmail.com

Received: 31 January 2021

Accepted: 5 April 2021

\begin{abstract}
:
Background: Immune thrombocytopenia (ITP) is an autoimmune disease with excessive platelet destruction and reduced platelet production. Progranulin (PGRN) has a protective effect against autoimmune diseases by competitive binding tumor necrosis factor- $\alpha$ receptors. Thus, we assessed the serum progranulin level in relation to platelet count in ITP patients, pre-and post-induction of corticosteroid therapy. Methods: A case - control study was conducted on 30 ITP patients and 30 apparently healthy subjects serving as a control group. Platelet count and serum progranulin levels were measured in newly diagnosed ITP patients before and 3-7 days after starting corticosteroid treatment. Results: The mean serum level of PGRN was significantly higher in ITP patients pretreatment compared to healthy control subjects $(\mathrm{P}<0.001)$. After 3-7 days of treatment of ITP patients with corticosteroid; the platelets count increased significantly, whereas serum PGRN level decreased significantly ( $\mathrm{P}<0.001$ each). Serum PRGN showed a significant negative correlation with platelets count pre-steroid
\end{abstract} treatment and a significant positive correlation with platelets count post-steroid treatment.

Conclusion: The elevated serum PGRN levels in ITP patients supports its involvement in the disease pathogenesis. The inversely correlated serum PGRN levels with platelets count in ITP patients before and after treatment induction suggest that PGRN may be a useful biomarker that helps the diagnosis, treatment decisions and follow up of ITP patients.

Keywords: Progranulin, Immune Thrombocytopenia, Biomarker, Protective. 


\section{Introduction:}

Immune thrombocytopenia (ITP) is an autoimmune disease characterized by excessive platelet destruction and reduced platelet production. [1] ITP is defined in a patient with generalized purpuric eruption, when peripheral blood platelet count is less than $100 \times 10^{9} / \mathrm{L}$ while total white blood cell count and hemoglobin level are normal. [2]

Platelet destruction in ITP is mediated by an immunoglobulin G autoantibody which develops against platelet membrane proteins. The antibody-coated platelets are cleared progressively by macrophages in spleen. T-cell mediated cytotoxicity is proposed to reduce platelet production where cytotoxic $T$ cells attack megakaryocytes in the bone marrow. [3]

The guidelines of the American Society of Hematology (ASH) for a newly diagnosed adult with ITP recommend corticosteroids, intravenous immune globulin (IVIG) or Rh (D) Immune Globulin (RhIg) as first-line therapy. The fastest platelet count responses can be achieved with IVIG within 12-48 hours, then high-dose dexamethasone within 1-2 days and standard-dose prednisone within 2-4 days. [4]

Progranulin (PGRN) is a 593 amino acids glycoprotein. It is composed of repeats of granulin module like beads on a chain. PGRN has been shown to be involved in stimulating cell proliferation and regulating neuropathology, cancer cell proliferation, infection and wound healing. [5] It affects directly the growth, migration, and invasion of human colon cancer cells. [6]

Progranulin has a protective effect against autoimmune diseases by competitively binding tumor necrosis factor- $\alpha$ (TNF- $\alpha$ ) receptors (TNFR-1 and -2). [7] However, the exact role of progranulin in ITP remains unclear. Thus, we aimed to assess serum progranulin level in relation to platelet count in ITP patients, pre-and post-induction of corticosteroid therapy.

\section{Subjects and methods}

\section{Subjects}

The present study was conducted at Internal Medicine department of Tanta University Hospital and Clinical and Chemical Pathology department of Benha University Hospital between November 2018 and May 2019 on a total of 60 subjects were enrolled in this case - control study, included 30 patients diagnosed with ITP according to the ASH criteria for diagnosis of ITP (platelet count less than $100 \times 10^{3} / \mu 1$ without morphologic evidence for dysplasia in the peripheral blood film) after exclusion of 
other causes of primary and secondary thrombocytopenia. They were further subdivided into pre-treatment and posttreatment where they are newly diagnosed ITP patients before staring corticosteroid therapy and 3-7 days after starting corticosteroid treatment, respectively. Any case presented with diabetes mellitus or other autoimmune disorders was excluded from this study.

In addition, 30 apparently healthy volunteers without history of chronic, inflammatory, autoimmune or malignant diseases or under any kind of medical treatment were enrolled as control group. The study was approved by the local ethics committee on research involving human subjects in Faculty of Medicine, Benha University in agreement with the Declaration of Helsinki. [8] Informed consent was obtained from each subject prior to participation.

\section{Methods}

All patients underwent full history taking and comprehensive clinical examination by a clinical hematologist. Laboratory investigations included complete blood count and serum progranulin levels pre- and post-corticosteroid therapy induction. Serum progranulin (PRGN) was detected by a double-antibody sandwich ELISA Kit for research use (Cat\#: E-02467HU, CloudClone Crop., USA). The sensitivity by this assay was $10 \mathrm{pg} / \mathrm{ml}$.

\section{Statistical Analysis}

The collected data were tabulated and analyzed using SPSS version 21 software (Spss Inc, Chicago, ILL Company). Chi square test $\left(X^{2}\right)$ or Monte Carlo exact test (MC) was used to analyze categorical variables. Quantitative data were tested for normality using Shapiro-Wilks test, assuming normality at $\mathrm{P}>0.05$. Differences among two groups regarding parametric variables were analyzed by student t-test. Difference among two groups regarding non-parametric variables was analyzed by Mann Whitney test (U).

Relation between two parametric variables pre- and post-treatment was done by paired t-test. While, between two non-parametric variables were done by Wilcoxon signed rank test. Parametric correlations were assessed by Pearson's correlation coefficient $(r)$.

ROC curve was constructed to detect cut off value of PGRN with optimum sensitivity and specificity in prediction of cases. The accepted level of significance in this work was stated at 0.05 . 


\section{Results}

The mean age of ITP patients $33.2 \pm 8.32$ years was significantly lower than the mean age of healthy controls $45.03 \pm 7.3$ years $(\mathrm{P}<0.001)$. The studied ITP patients were 14 males and 16 females who were matched with control subjects 20 males and 10 females (P 0.118). Platelets count was significantly decreased in ITP patients than controls $(\mathrm{P}<0.001)$ and hemoglobin level and total white blood cell count did not differ among studied groups before induction of corticosteroid therapy in ITP patients.

The mean serum level of PGRN was significantly higher in ITP patients pretreatment compared to healthy control subjects ( $\mathrm{P}<0.001)$. Table (1)

According to platelets count in studied ITP patients before starting corticosteroid treatment, bleeding symptoms did not differ significantly (P 0.333). While, serum PRGN level was significantly higher in ITP patients with platelets count less than or equal to 10 x $10^{3} / \mu 1$ rather than that in patients with platelets count more than $10 \times 10^{3} / \mu 1(\mathrm{P}$ 0.028). Table (2)

After 3-7 days of treatment of ITP patients with corticosteroid; the platelets count increased significantly ( $\mathrm{P}<0.001)$, whereas serum PGRN level decreased significantly ( $\mathrm{P}<0.001)$. Table (3)

It was found that serum PRGN level showed a significant negative correlation with platelets count pre-steroid treatment $(r=-$ $0.384, \mathrm{P}$ 0.036) and a significant positive correlation with platelets count post-steroid treatment ( $r=0.457$, P 0.011). Fig (1)

The diagnostic performances of PRGN to discriminate between ITP patients and healthy control indicated that at a serum PRGN cut-off value $>1592.5 \mathrm{pg} / \mathrm{ml}$ the sensitivity, specificity, positive predictive value and negative predictive value were $100 \%$ each with an excellent area under the ROC curve of 1.00 (P <0.001). Fig (2) 
Table 1. Demographic and laboratory characteristics of the two studied groups (pre-treatment):

\begin{tabular}{|c|c|c|c|c|c|}
\hline & & $\begin{array}{l}\text { ITP patients } \\
(n=30)\end{array}$ & $\begin{array}{l}\text { Control } \\
(\mathrm{n}=30)\end{array}$ & Test & $\mathbf{P}$ \\
\hline Age ( & & $33.2 \pm 8.32$ & $45.03 \pm 7.3$ & $126.5^{*}$ & $<0.001$ \\
\hline \multirow{2}{*}{ Sex } & Male & $14(46.7 \%)$ & $20(66.7 \%)$ & \multirow{2}{*}{$2.443 * *$} & \multirow{2}{*}{0.118} \\
\hline & Female & $16(53.3 \%)$ & $10(33.3 \%)$ & & \\
\hline \multicolumn{2}{|c|}{$\mathrm{Hb}(\mathrm{g} / \mathrm{dl})$} & $11.7 \pm 1.12$ & $11.8 \pm 0.85$ & $0.272 * * *$ & 0.787 \\
\hline \multicolumn{2}{|c|}{ WBCs $\left(\mathbf{x 1 0}^{3} / \mu \mathrm{l}\right)$} & $7.7 \pm 2.68$ & $7.6 \pm 1.83$ & $431.00 *$ & 0.779 \\
\hline \multicolumn{2}{|c|}{ Platelet count $\left(\times 10^{3} / \mu \mathrm{l}\right)$} & $17.2 \pm 5.17$ & $242.2 \pm 68.69$ & $17.89 * * *$ & $<0.001$ \\
\hline \multicolumn{2}{|c|}{ PGRN (pg/ml) } & $3655.00 \pm 1373.21$ & $858.1 \pm 288.26$ & $0.000 *$ & $<0.001$ \\
\hline
\end{tabular}

Data represented as mean \pm SD and number (percentage).

*Mann-Whitney U-test, ${ }^{* *}$ Chi-square $\chi 2$-test, ${ }^{* * *}$ Student t-test.

Table 2. Relation between bleeding symptoms, PGRN level and platelets count in studied ITP patients pretreatment:

\begin{tabular}{|c|c|c|c|c|}
\hline & $\begin{aligned} & \text { Platelet } \\
\leq & 10 \times 10^{3} / \mu \mathrm{l}\end{aligned}$ & $\begin{array}{c}\text { Platelet } \\
>10 \times 10^{3} / \mu \mathrm{l}\end{array}$ & Test & $\mathbf{P}$ \\
\hline \multicolumn{5}{|l|}{ Bleeding symptoms } \\
\hline Ecchymosis, purpura $(n=12,40 \%)$ & $1(8.3 \%)$ & $11(91.7 \%)$ & & \\
\hline $\begin{array}{l}\text { Bleeding per gum, nose, hematemesis } \\
(\mathrm{n}=16,53.3 \%)\end{array}$ & $2(12.5 \%)$ & $14(87.5 \%)$ & $2.596^{*}$ & 0.333 \\
\hline $\begin{array}{l}\text { Unusual heavy menstruation } \\
(\mathrm{n}=2,6.67 \%)\end{array}$ & $1(50 \%)$ & $1(50 \%)$ & & \\
\hline PGRN (pg/ml) & $5417.5 \pm 1876.53$ & $3383.9 \pm 1091.50$ & $16.00 * *$ & 0.028 \\
\hline
\end{tabular}

Data represented as number (percentage) and mean $\pm \mathrm{SD}$.

*Monte Carlo exact test, **Mann-Whitney U-test.

Table 3. Comparison between platelets count and serum PGRN levels in ITP patients pre- and post-treatment:

\begin{tabular}{lcccc}
\hline & Pre-treatment & Post-treatment & Test & P \\
\hline Platelet $\left(\mathrm{x} 10^{3} / \mu \mathrm{l}\right)$ & $17.2 \pm 5.17$ & $66.9 \pm 14.19$ & $18.015^{*}$ & $<\mathbf{0 . 0 0 1}$ \\
PGRN $(\mathrm{pg} / \mathrm{ml})$ & $3655.00 \pm 1373.21$ & $1906.7 \pm 720.86$ & $4.783^{* *}$ & $<\mathbf{0 . 0 0 1}$ \\
\hline
\end{tabular}

Data represented as mean $\pm \mathrm{SD}$

* Paired t-test, ** Wilcoxon signed rank test. 

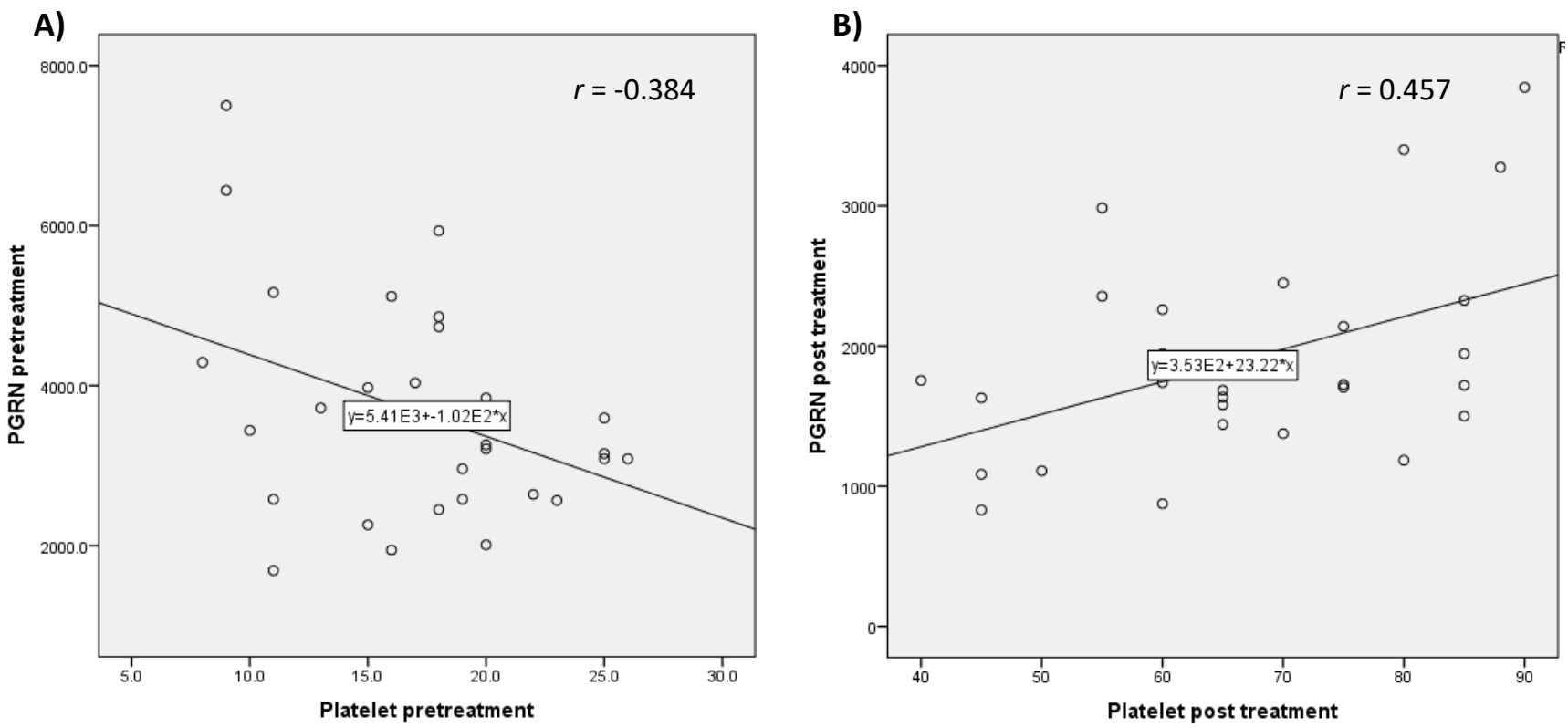

Figure 1. Correlation between serum PGRN level and platelets count in studied ITP patients; A) pre-treatment and B) post-treatment.

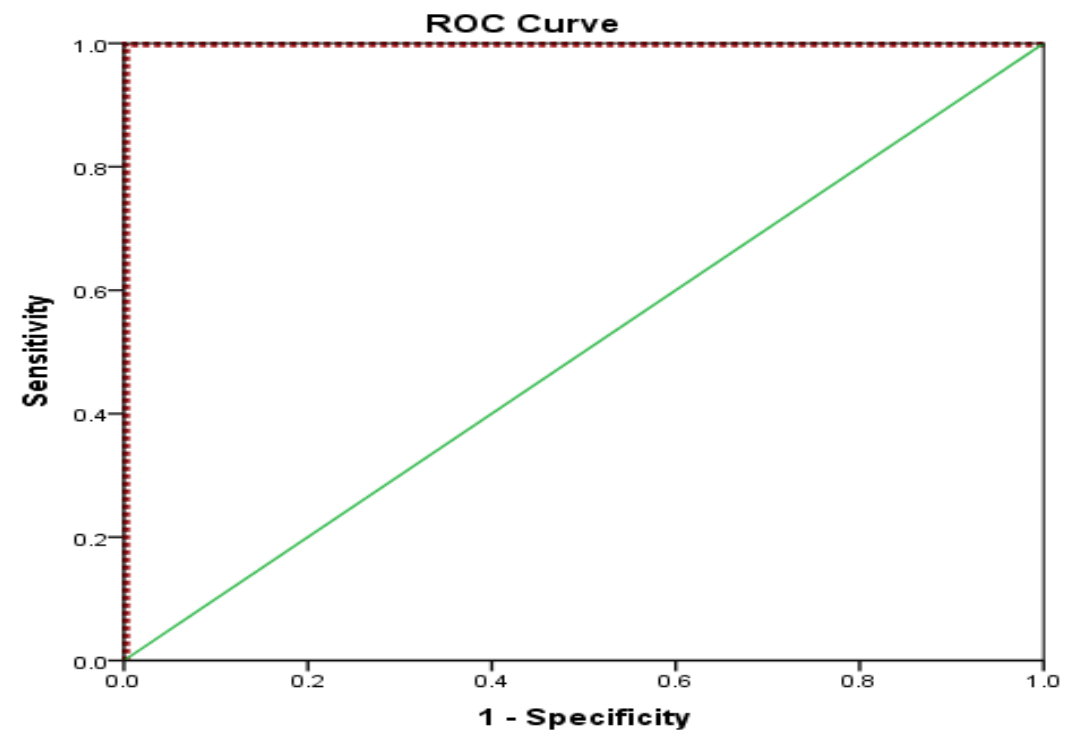

Figure 2. ROC curve for serum PRGN to diagnose ITP patients from healthy controls

\section{Discussion}

Progranulin has protective effects toward autoimmune diseases. It enhances the Treg proliferation and decreases the inhibitory effect of tumor necrosis factor- $\alpha(\mathrm{TNF}-\alpha)$ on 
them via its competitive binding with TNF- $\alpha$ receptors (TNFR1 and TNFR2). As a vital player in inhibiting autoimmune diseases, the role of PGRN in ITP remains unclear. [9]

This case-control study was conducted on 30 idiopathic thrombocytopenic purpura (ITP) patients, before and 3-7 days after starting corticosteroid therapy, and 30 apparently healthy subjects as control group. The mean age of ITP patients $(33.2 \pm 8.32$ years) was significantly lower than the controls $(45.03 \pm 7.3$ years $)(\mathrm{P}<0.001)$. Both groups were sex-matched $(\mathrm{P}=0.118)$. They were 14 males and 16 females ITP patients and 20 males and 10 females control subjects. In a previous Egyptian study, ITP patients and healthy controls were age and sex-matched (P 0.798 and 0.349, respectively) as the mean age of ITP patients was $31.37 \pm 5.99$ years and of controls was $30.95 \pm 7.19$ years with 53 female patients $(88.3 \%)$ and 16 female controls (80\%). [10] The present study showed that at time of presentation, the bleeding symptoms in ITP patients were ecchymosis and /or purpura in $40 \%$, bleeding per gum, nose and/or hematemesis in $53.3 \%$ and $6.7 \%$ of female patients had heavy menstruation. The relation between thrombocytopenia and bleeding is well documented. However, there is no clear evidence of a direct correlation between the degrees of thrombocytopenia and bleeding symptoms, especially at lower platelet counts [11]. It was demonstrated that most ITP patients manifest with hemorrhagic symptoms ranging from mild cutaneous bleeding to severe life-threating bleeding complications. [12]. Along with our results, a study had revealed that $47 \%$ of ITP patients had bled for a few days and $27 \%$ had bruised easily for several weeks or months "easy bruising syndrome". [13]

According to ASH guidelines for ITP diagnosis [4], ITP patients had a pretreatment significantly lower platelets count compared with control group ( $\mathrm{P}<0.001)$, while, no significant differences were detected in hemoglobin level and total white blood cell count ( $\mathrm{P}>0.05$ each).

In current work, mean serum PGRN level $(3655.00 \pm 137.21 \mathrm{pg} / \mathrm{ml})$ was significantly elevated in newly diagnosed pre-treatment ITP patients compared to healthy control subjects $(858.1 \pm 288.26 \mathrm{pg} / \mathrm{ml})(\mathrm{P}<0.001)$. After 3-7 days of corticosteroid therapy induction, significant increase in platelets count was observed with a mean $66.9 \pm$ $14.19 \times 10^{3} / \mu 1$ (range 40-90 x 10\% $/ \mu 1$ ). While, serum PGNR level was significantly decreased $1906.7 \pm 720.86 \mathrm{pg} / \mathrm{ml}$ compered to patients before treatment ( $\mathrm{P}<0.001$ each). It was found that serum PRGN level has a 
significant negative correlation with platelets count pre-steroid treatment $(r=-$ 0.384, P 0.036) and a significant positive correlation with platelets count post-steroid treatment ( $r=0.457, \mathrm{P}$ 0.011). This was in agreement with $\mathrm{Yu}$ et al.(2018) who reported an increased PGRN levels in ITP patient plasma, which were reduced after treatment. They found that plasma PGRN levels were negatively correlated with platelet count of ITP patients. [14]

PGRN was suggested to have an immunosuppressive effect on ITP being a protective regulator in ITP animal models, as PGRN deficiency led to fewer Treg cells in ITP mouse spleens. [14] ITP is a complex disease that is diagnosed mainly by exclusion. Up till now, no specific biomarker can support the differential diagnosis or treatment decisions for ITP. Various studies have reported the impaired balance of $\mathrm{T}$ helper cytokines (Th1/Th2) and $\mathrm{T}$ regulatory cell cytokines in ITP pathogenesis; with controversial $[15,16]$ and contradictory [17] data regarding Th1 cytokine profiles in ITP, whereas, the Tregs cytokine, transforming growth factor- $\beta 1$ (TGF $\beta 1$ ), has been found to be downregulated in ITP. [18] Lower levels of TGF $\beta 1$ correlate with defective Treg number and function in ITP patients. [19,20]
PGRN has been proved to protect against autoimmune diseases such as rheumatoid arthritis [21,22], osteoarthritis [23], inflammatory bowel disease [24] and systemic lupus erythematosus. [25,26]

In conclusion, the inversely correlated serum PGRN levels with platelets count in ITP patients before and after treatment induction suggest that PGRN may be a useful biomarker that helps the diagnosis, treatment decisions and follow up of ITP patients. Furthermore, its evidenced effect on Treg proliferation might make PRGN a potential therapeutic strategy for management of ITP.

\section{References:}

[1] Feng Q, Xu M, Yu YY, Hou Y, Mi X, Sun YX, et al. High-dose dexamethasone or all-transretinoic acid restores the balance of macrophages towards M2 in immune thrombocytopenia. J Thromb Haemost 2017;15:1845-58. https://doi.org/10.1111/jth.13767.

[2] Arnold DM. Immune thrombocytopenia: getting back to basics. Am J Hematol 2012;87:841-2. https://doi.org/10.1002/ajh.23287.

[3] Neunert C, Noroozi N, Norman G, Buchanan GR, Goy J, Nazi I, et al. Severe bleeding events in adults and children with primary immune thrombocytopenia: a systematic review. J Thromb Haemost 2015;13:457-64. https://doi.org/10.1111/jth.12813.

[4] Neunert C, Terrell DR, Arnold DM, Buchanan $\mathrm{G}$, Cines DB, Cooper $\mathrm{N}$, et al. American 
Society of Hematology 2019 guidelines for immune thrombocytopenia. Blood Adv 2019;3:3829-66.

https://doi.org/10.1182/bloodadvances.2019000 966.

[5] Bateman A, Cheung ST, Bennett HPJ. A Brief Overview of Progranulin in Health and Disease. Methods Mol Biol 2018;1806:3-15. https://doi.org/10.1007/978-1-4939-8559-3_1.

[6] Zhao J, Li X, Liu J, Jiang W, Wen D, Xue H. Effect of Progranulin on Migration and Invasion of Human Colon Cancer Cells. J Coll Physicians Surg Pak 2018;28:607-11. https://doi.org/10.29271/jcpsp.2018.08.607.

[7] Jian J, Li G, Hettinghouse A, Liu C. Progranulin: A key player in autoimmune diseases. Cytokine 2018;101:48-55. https://doi.org/10.1016/j.cyto.2016.08.007.

[8] WMA, World Medical Association. WMA DECLARATION OF HELSINKI - ETHICAL PRINCIPLES FOR Scientific Requirements and Research Protocols. World Med Assoc 2013:29-32.

[9] Tang W, Lu Y, Tian Q-Y, Zhang Y, Guo F-J, Liu G-Y, et al. The growth factor progranulin binds to TNF receptors and is therapeutic against inflammatory arthritis in mice. Science 2011;332:478-84.

https://doi.org/10.1126/science.1199214.

[10] Gad Allah H, Moussa M, El-Ghammaz A, Ali B. Role of interleukin-27 in immune thrombocytopenic purpura and its impact on disease response. Egypt J Haematol 2016;41:116-20. https://doi.org/10.4103/11101067.196177.

[11] Kuter DJ, Bussel JB, Newland A, Baker RI, Lyons RM, Wasser $\mathrm{J}$, et al. Long-term treatment with romiplostim in patients with chronic immune thrombocytopenia: safety and efficacy. Br J Haematol 2013;161:411-23. https://doi.org/10.1111/bjh.12260.

[12] Rottenstreich A, Israeli N, Roth B, Elchalal U, Amsalem $\mathrm{H}$, Da'as $\mathrm{N}$, et al. Risk factors associated with neonatal thrombocytopenia in pregnant women with immune thrombocytopenic purpura. J Matern Neonatal Med Off $\mathbf{J}$ Eur Assoc Perinat Med Fed Asia Ocean Perinat Soc Int Soc Perinat Obstet 2020;33:1572-8. https://doi.org/10.1080/14767058.2018.152389 1.

[13] Vantelon JM, Godeau B, André C, Bierling P. Screening for autoimmune markers is unnecessary during follow-up of adults with autoimmune thrombocytopenic purpura and no autoimmune markers at onset. Thromb Haemost 2000;83:42-5.

[14] Yu Y, Shi Y, Zuo X, Feng Q, Hou Y, Tang W, et al. Progranulin facilitates the increase of platelet count in immune thrombocytopenia. Thromb Res 2018;164:24-31. https://doi.org/10.1016/j.thromres.2018.02.137.

[15] Ogawara H, Handa H, Morita K, Hayakawa M, Kojima J, Amagai H, et al. High Th1/Th2 ratio in patients with chronic idiopathic thrombocytopenic purpura. Eur J Haematol 2003;71:283-8. https://doi.org/10.1034/j.16000609.2003.00138.x.

[16] Ma D, Zhu X, Zhao P, Zhao C, Li X, Zhu Y, et al. Profile of Th17 cytokines (IL-17, TGF-beta, IL-6) and Th1 cytokine (IFN-gamma) in patients with immune thrombocytopenic purpura. Ann Hematol 2008;87:899-904. https://doi.org/10.1007/s00277-008-0535-3.

[17] Panitsas FP, Mouzaki A. Effect of splenectomy on type-1/type- 2 cytokine gene expression in a 
patient with adult idiopathic thrombocytopenic purpura (ITP). BMC Blood Disord 2004;4:4. https://doi.org/10.1186/1471-2326-4-4.

[18] Ma L, Liang Y, Fang M, Guan Y, Si Y, Jiang F, et al. The cytokines (IFN-gamma, IL-2, IL-4, IL-10, IL-17) and Treg cytokine (TGF-beta1) levels in adults with immune thrombocytopenia. Pharmazie 2014;69:694-7.

[19] Andersson P-O, Olsson A, Wadenvik H. Reduced transforming growth factor-beta1 production by mononuclear cells from patients with active chronic idiopathic thrombocytopenic purpura. $\mathrm{Br} \mathrm{J}$ Haematol 2002;116:862-7.

https://doi.org/10.1046/j.0007-

1048.2002.03345.x.

[20] Fahim NMA, Monir E. Functional role of CD4+CD25+ regulatory $\mathrm{T}$ cells and transforming growth factor-beta1 in childhood immune thrombocytopenic purpura. Egypt J Immunol 2006;13:173-87.

[21] Chen J, Li S, Shi J, Zhang L, Li J, Chen S, et al. Serum progranulin irrelated with Breg cell levels, but elevated in RA patients, reflecting high disease activity. Rheumatol Int 2016;36:359-64.

https://doi.org/10.1007/s00296-015-3372-4.

[22] Fouad NA, Nassr MH, Fathi HM, Zaki OM, Negm AA, Senara SH. Potential value of serum progranulin as an activity biomarker in rheumatoid arthritis patients: Relation to musculoskeletal ultrasonographic evaluation. Egypt Rheumatol 2019;41:93-7. https://doi.org/https://doi.org/10.1016/j.ejr.2018 .07 .004 .

[23] Zhao Y-P, Liu B, Tian Q-Y, Wei J-L, Richbourgh B, Liu C-J. Progranulin protects against osteoarthritis through interacting with TNF- $\alpha$ and $\beta-$ Catenin signalling. Ann Rheum Dis 2015;74:2244-2253. https://doi.org/10.1136/annrheumdis-2014205779.

[24] Wei F, Zhang Y, Jian J, Mundra JJ, Tian Q, Lin $\mathrm{J}$, et al. PGRN protects against colitis progression in mice in an IL-10 and TNFR2 dependent manner. Sci Rep 2014;4:7023. https://doi.org/10.1038/srep07023.

[25] Tanaka A, Tsukamoto H, Mitoma H, Kiyohara C, Ueda N, Ayano M, et al. Serum progranulin levels are elevated in patients with systemic lupus erythematosus, reflecting disease activity. Arthritis Res Ther 2012;14:R244. https://doi.org/10.1186/ar4087.

[26] Qiu F, Song L, Ding F, Liu H, Shu Q, Yang N, et al. Expression level of the growth factor progranulin is related with development of systemic lupus erythematosus. Diagn Pathol 2013;8:88. https://doi.org/10.1186/1746-15968-88.

To cite this article: Noha M. Attia, Adel M. Agha, Safaa E. Abass, Ola S. El-Shimi. The Relation between Serum Progranulin and Platelet Count in Immune Thrombocytopenia Patients. BMFJ 2021;38(1): 334-343. DOI: 10.21608/bmfj.2021.60711.1376 